\title{
HOST ACQUISITION BY ORNITHODOROS CAPENSIS NEUMANN (IXODOIDEA : ARGASIDAE)
}

\author{
by I. HUMPHERY-SMITH and D. E. MOORHOUSE*
}

\begin{abstract}
SUMMARY. Forty percent of white-capped noddy tern, Anous minutus, nests tagged in January 1977 were re-occupied the following nesting season in February 1978. This re-use of nests allows host acquisition by $O$. capensis, as the ticks remain in the core of the abandoned nest during the non-nesting season.

\section{L'acquisition de l'hôte par Ornithodoros capensis Neumann (Ixodoidea : Argasidae).}

RÉSUMÉ. Quarante pour cent des nids d'Anous minutus marqués en janvier 1977 étaient ré-utilisés lors de la période de nidification suivante. Cette ré-utilisation permet à $O$. capensis l'acquisition d'un hôte, les tiques demeurant au sein du nid en dehors de cette période. En laboratoire, seule une femelle (sur 18 tiques) a survécu à 37 mois de jeûne. Ces tiques femelles couvant leurs œufs étaient récoltées dans les feuilles recroquevillées du nid. La composition du peuplement observée dès l'abandon d'un nid rend compte de l'activité reproductrice des tiques pendant la période de nidification de l'hôte.

\section{Introduction}

Amerson (1968) has reviewed the host range and zoogeography of the argasid tick, Ornithodoros capensis Neumann. It has been recovered from avian nests on numerous occasions (Hobart and Whalley 1954; Rageau and Vervent 1958; Philip 1965; Ramsay 1968; Amerson and Shelton 1976 and Hoogstraal, Kaiser and Easton 1976). On Heron Island, Great Barrier Reef, Queensland, Australia, O. capensis were found in nests of white-capped noddy terns (Anous minutus), reef herons (Egretta sacra) and banded land rails (Rallus philippensis) (personal observations).

Nest infestation rates as high as $93 \%$ for brown noddy terns (Anous stolidus) have been reported on Sand Island, Johnston Atoll, Central Pacific, where the seasonal incidence was directly dependent on fluctuations of bird populations, in that increased tick numbers could be directly correlated to increases in seasonal populations of breeding birds (Amerson and Shelton 1976).

The present study was instigated because preliminary surveys showed that the weathered cores of nests, estimated to be 10 months old, from the previous breeding

* Department of Parasitology, University of Queensland, St Lucia, Queensland, Australia 4067.

Accepté le ${ }_{5} 5$ décembre 1980. 
season were regularly found to contain adult ticks of both sexes. Hoogstraal (personal communication) observed that on Bird Island, Seychelles, an area abandoned by sooty terns (Sterna fuscata nubilosa) one year previously, was still heavily infested by $O$. capensis.

Shipway (1969) estimated that there were 8,300 white-capped noddy tern nests on Heron Island during the breeding season. Thus, given the number of nest sites required in this restricted area, it is reasonable to expect some nest sites and indeed nests, may be re-used. This hypothesis and its degree of efficiency as a means of host acquisition is investigated here.

\section{Materials and methods}

Heron Island is a coral cay in the Capricorn Group of islands in the Great Barrier Reef, situated $69 \mathrm{~km}$ east of Cape Capricorn at 23026'S and 151055'E. It has an area of 16.8 hectares characterised by central climax forest of Pisonia grandis, with various seral stages occurring closer to the shore (Gillham, 1961).

The host, Anous minutus, is a sedentary species, breeding, and many remaining, on Heron Island throughout the year. However, migrations of $640 \mathrm{~km}$ have been reported (McClure, 1974). These birds forage up to $30 \mathrm{~km}$ from nest sites, and feed mostly in lagoons and in the reef surf (Hulsman, 1977). Nest platforms (fig. 1) are made from large quantities of guano and Pisonia leaves. The nesting season is between October and March (Kikkawa, 1970).

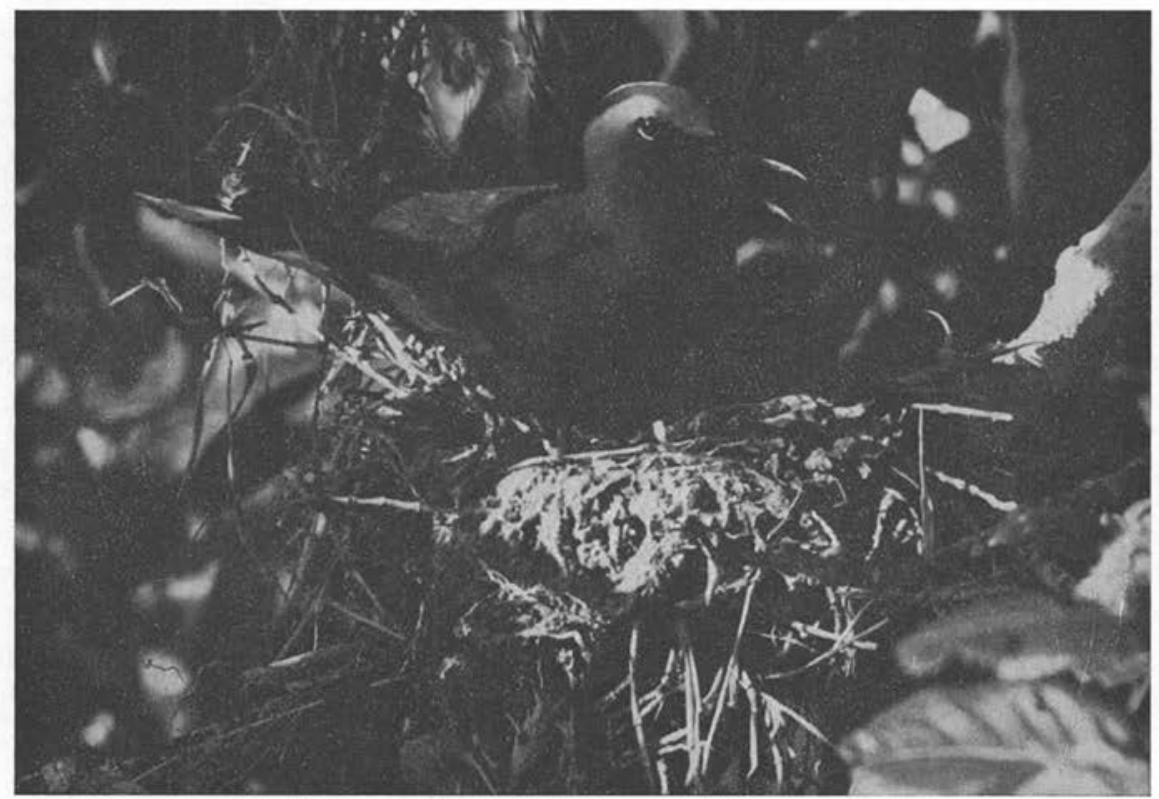

FIG. I - An adult Anous minutus on a nest. 
Between 1st and 9th January 1977, 95 nests were marked by knotting strips $(1 \mathrm{~m} \times 3 \mathrm{~cm})$ of green plastic around the supporting branch, as close to the nest as possible. Care was taken to minimise disturbance of the nesting material. Later, for the purpose of recording, the knot in the plastic was considered as the tagunkotted strips of the plastic were disregarded. Tagging was restricted to branches of Pisonia grandis, Casuarina equisetifolia, and Pandanus tectorius 2-5 $\mathrm{m}$ above ground level. The island and position of trees with tagged nests were mapped. Tagged nests were re-surveyed on 25th February 1978. A sample of 7 female and 11 male $O$. capensis were collected from nests in January, 1977 and kept in a glass vial with a gauze top in a laboratory subjected to varying temperature and humidity. A small piece of paper towelling was placed in the vial and moistened at irregular intervals of 1 week to 2 months. Longevity since collection was recorded in the absence of any nourishment.

At this same time one nest which had recently been abandoned, as evidenced by unweathered guano and a well-formed platform, was dismantled leaf by leaf and the numerous leaf-folds examined for ticks. The dry nest core was broken manually, a little at a time, and examined in a white dissection tray.

\section{Results}

Of the 95 tags, 11 were not found and 4 were found without accompanying branch or nest. Several pieces of tags were found incorporated in nests, and much of this tag loss is attributed to the activity of nesting birds. The following results are presented as a percentage of the remaining 80 tags.

Twenty-one $(26.2 \%)$ nests were found to be in use, while $11(13.8 \%)$ nests were found to have been re-used during the early part of the 1977-78 breeding season, but by February had been abandoned. They were easily distinguished by the unweathered guano and well-formed platforms, from the $20(25 \%)$ nests, which while still in place, had not been re-occupied. Thus, a total of $40 \%$ of tagged nests had been re-used in the following breeding season. The formidable size of some nests may be evidence of their use over a number of years. The amount of material re-used in nest building varied considerably, from the simple incorporation of a well-weathered core to the use of a well-preserved nest of considerable size.

The 11 nests abandoned after a short period of re-use, may give an indication of high mortality among the nest-age chicks. As observations were made towards the end of the nesting season, this estimate may also include a proportion where the fledglings had left the nest. Nonetheless, there was a large number of chicks seen wandering on the ground unable to regain their nesting platforms, and numerous chick carcases.

Twenty-eight $(35 \%)$ nests were lost to weathering during the 13 months since tagging. In $19(23.8 \%)$ cases, the nests had been dislodged, while with the other 9 $(11.2 \%)$ the branch had either broken off or withered, and was no longer suitable for nesting. 
Of the 7 female and 11 male ticks kept in the laboratory from January, 1977, 3 females and 5 males survived for 13 months; 2 years after collection only 1 female remained. This female died the following February after 37 months without nourishment.

The recently-abandoned nest, when dismantled, was found to contain 62 females; 49 males; 46 nymphs; 303 larvae; 175 eggs; 99 empty eggs; 26 larval exuviae (all 1 size) and 164 nymphal exuviae ( 2 sizes). Nine females were observed to be brooding a mean of 34.4 eggs (range 16-43) within leaf-folds and their bodies were in contact with the eggs. Similarly, brooding has been observed with 2 undescribed species of Ornithodoros (Reticulinasus) parasitizing bats in Papua New Guinea (Moorhouse, unpublished).

\section{Discussion}

As Pisonia grandis is a poorly wooded tree and as the island is influenced by tropical cyclones; the proportion of nests and therefore ticks lost due to weathering, is expected to vary substantially from year to year. The last severe cyclone was in April 1972 which caused considerable tree defoliation with many trees being uprooted. Presumably most nests must have been lost at this time.

The longevity obtained in the laboratory, in far from ideal conditions, indicates that $O$. capensis is quite capable of surviving 1 and possibly 2 non-breeding seasons in the nest core. The survival rate is, however, likely to be affected by weather conditions, such as temperature and humidity, which prevail during the nonnesting season. In $40 \%$ of cases in this study, the old nest was utilised as a base for building the new season's nest. With the arrival of the brooding adult birds and later the chicks, the ticks and their developmental stages are provided with an immobile food source. The reproductive activity and tick numbers obtained from the recentlyabandoned nest indicate the efficiency of the parasite in relating its reproductive cycle to that of the host.

This mechanism of host acquisition is dependent on large numbers of birds in a limited area regularly competing for a limited number of suitable nesting sites. This is often the case in breeding colonies of marine birds and may thus be used by other Argasid ticks found either near nesting sites or in nesting material of marine birds. Kaiser and Hoogstraal (1974) presumed this to be the mechanism which ensured the survival of a population of Argas (Argas) falco parasitising kestrels in Western Australia.

Acknowleagements. We wish to thank Diana Smith for her assistance in the field and the Great Barrier Reef Committee for providing facilities on Heron Island, and Professor J. Kikkawa for permission to publish his original photograph. 


\section{REFERENCES}

Amerson A. B. JR : Tick distribution in the Central Pacific as influenced by sea bird movement, J. Med. Ent., 1968, 5, 332-339.

Amerson A. B. Jr, Shelton P. C. : The Natural History of Johnston Atoll, Central Pacific Ocean Atoll Res. Bull. 1976, 192, 1-479.

Gillham M. E. : Coral cay vegetation, Heron Island, Great Barrier Reef, Proc. R. soc. Qld., I961, $73,79-92$.

Hobart J., Whalley P. E. S. : Occurrence of a Species of Ornithodoros in Britain, Nature, 1954 ${ }_{1} 74,936$.

Hoogstraal H., Kaiser M. N., Easton E. R. : Ornithodoros (Alectorobius) capensis Neumann (Ixodoidea : Argasidae) parasitizing a human and birds nesting on islands in East African lakes, J. Med. Ent., 1976, 12, 703-704.

Hulsman C. : Feeding and breeding biology of six sympatric species of tern (Laridae) at One Tree Island, Great Barrier Reef, Ph.D. thesis, University of Qld, I977.

Kaiser M. N., Hoogstraal H. : Observations on the Subgenus Argas (Ixodoidea : Argasidae, Argas) 9. A. (A.) falco, New Species, parasitizing kestrels in Western Australia, Ann. Ent. Soc. Amer., 1974, 67, 5-10.

Kikkawa J. : Birds recorded at Heron Island, Sunbird, 1970, 1, 34-48.

McClure H. E. : Migration and Survival of the Birds of Asia, U.S. Army Medical Component SEATO Medical Project, Bangkok, Thailand, 1974.

PHILIP C. B. : Hughes virus, a new arboviral agent from marine bird ticks, J. Parasitol., 1965, 51 252.

Rageau J., Vervent G. : Présence d'Ornithodoros (Acariens Argasidae) aux Iles Chesterfield (Pacifique Sud) Bull. Soc. Path. Exot., 1958, 51, 238-244.

Ramsay G. W. : The argasid tick Ornithodoros capensis Neumann, from the Kermadec Islands. NZ Entomologist., 1968, 4, 32-34.

Shipway A. K. : The numbers of terns and shearwaters nesting on Heron Island in $1965, E m u$, 1969, 69, 108-109. 